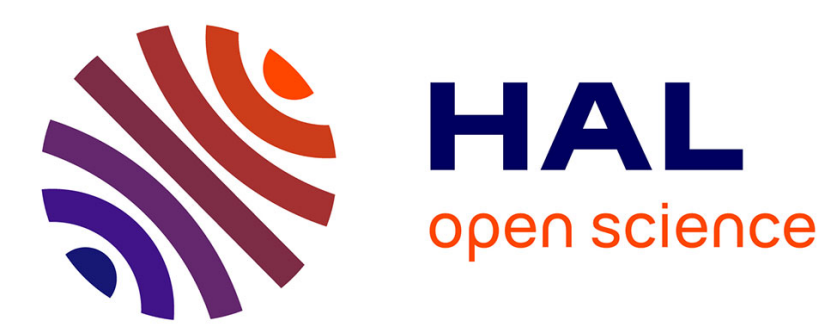

\title{
Regulation of Leaf Breakdown by Fungi in Streams: Influences of Water Chemistry
}

\author{
Keller Suberkropp, Eric Chauvet
}

\section{To cite this version:}

Keller Suberkropp, Eric Chauvet. Regulation of Leaf Breakdown by Fungi in Streams: Influences of Water Chemistry. Ecology, 1995, vol. 76 ( $\mathrm{n}^{\circ}$ 5), pp. 1433-1445. 10.2307/1938146 . hal-01308033

\section{HAL Id: hal-01308033 \\ https://hal.science/hal-01308033}

Submitted on 27 Apr 2016

HAL is a multi-disciplinary open access archive for the deposit and dissemination of scientific research documents, whether they are published or not. The documents may come from teaching and research institutions in France or abroad, or from public or private research centers.
L'archive ouverte pluridisciplinaire HAL, est destinée au dépôt et à la diffusion de documents scientifiques de niveau recherche, publiés ou non, émanant des établissements d'enseignement et de recherche français ou étrangers, des laboratoires publics ou privés. 


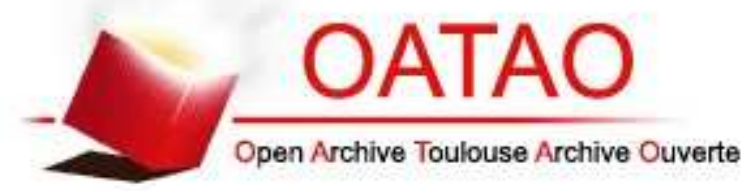

\section{Open Archive TOULOUSE Archive Ouverte (OATAO)}

OATAO is an open access repository that collects the work of Toulouse researchers and makes it freely available over the web where possible.

This is an author-deposited version published in : http://oatao.univ-toulouse.fr/ Eprints ID : 15681

To link to this article : DOI : $10.2307 / 1938146$

URL : http://dx.doi.org/10.2307/1938146

To cite this version : Suberkropp, Keller and Chauvet, Eric

Regulation of Leaf Breakdown by Fungi in Streams: Influences of

Water Chemistry. (1995) Ecology, vol. 76 (n 5). pp. 1433-1445.

ISSN 0012-9658

Any correspondence concerning this service should be sent to the repository administrator: staff-oatao@ listes-diff.inp-toulouse.fr 


\title{
REGULATION OF LEAF BREAKDOWN BY FUNGI IN STREAMS: INFLUENCES OF WATER CHEMISTRY ${ }^{1}$
}

\author{
KELLER SUBERKROPP \\ Department of Biological Sciences, University of Alabama, Tuscaloosa, Alabama 35487-0344 USA \\ ERIC Chauvet \\ Centre d'Ecologie des Systèmes Fluviaux, Centre National de la Recherche Scientifique, 29 rue Jeanne Marvig, \\ 31055 Toulouse Cedex, France
}

\begin{abstract}
We examined the influence of stream water chemistry on relationships between fungal activity and breakdown rates of yellow poplar (Liriodendron tulipifera) leaves in eight streams that varied with respect to $\mathrm{pH}$ and nutrient (nitrate and phosphate) concentrations. We also performed a reciprocal exchange experiment of leaves that had been colonized by microorganisms in two streams with contrasting water chemistries. Decomposer activity varied greatly depending on the stream in which the leaves were placed. Variation in breakdown rates of yellow poplar leaves was over 9-fold maximum ATP concentrations associated with leaves varied as much as 8-fold, and maximum sporulation rates of fungi associated with leaves varied over 80 -fold among streams. Among all streams, nitrate, phosphate, and temperature were positively correlated with one another and with decomposer biomass and activity. When hardwater streams were analyzed separately, nitrate concentration was the only variable that was significantly correlated with all measures of microbial activity and leaf breakdown. Consequently, nitrate concentration appeared to explain much of the variation we detected among streams. Responses to the reciprocal exchange experiment were rapid, with significant changes occurring within the first $5 \mathrm{~d}$ after the transfer. Leaves transferred from the hardwater stream containing relatively high concentrations of nitrate and phosphate to the softwater stream containing low concentrations of nutrients exhibited by large decreases in both ATP concentrations and sporulation rates, whereas ATP concentrations and sporulation rates increased when leaves received the reciprocal transfer. The fungi associated with decomposing leaves in streams appear to obtain a significant portion of their nutrients (e.g., nitrogen and phosphorus) from the water passing over the leaf surface. These results indicate that the chemistry of the water can be an important regulator of leaf breakdown in streams by affecting the activity of decomposer fungi.
\end{abstract}

Key words: aquatic hyphomycetes; ATP concentrations; decomposition; fungal reproductive activity; leaf-decomposing fungi; leaf litter; nitrogen; phosphorus; stream.

\section{INTRODUCTION}

In stream ecosystems, nutrients dissolved in the water, particularly nitrogen $(\mathrm{N})$ and phosphorus $(\mathrm{P})$, are important regulators of biotic processes. A number of studies have examined the effects of dissolved nutrients on rates of primary production and accumulation of algal biomass, and it is evident that autochthonous production and grazing food chains in streams are affected by such bottom-up controls (Bott 1983, Grimm and Fisher 1986, Pringle 1987, Meyer et al. 1988, Hart and Robinson 1990, Peterson et al. 1993, Rosemond et al. 1993). However, woodland streams are typically heterotrophic; i.e., more energy comes from allochthonous sources than from autochthonous production (Fisher and Likens 1973, Minshall et al. 1983). A significant portion of the allochthonous energy base enters streams in the form of leaf litter that is processed and used by decomposer microorganisms and detritivores. Current- ly, the effects of dissolved nutrients on detrital food chains, i.e., on rates of leaf breakdown and the activities of decomposer microorganisms, are not clearly understood.

In laboratory studies, amendments of $\mathrm{N}$, with or without $\mathrm{P}$, have generally been found to stimulate microbial activity, microbial biomass accumulation, and rates of leaf breakdown (Hynes and Kaushik 1969, Howarth and Fisher 1976, Fairchild et al. 1984). In streams, the effects of nutrients on leaf breakdown and the microbial communities associated with leaves are variable. The addition of $\mathrm{P}$ was shown to stimulate breakdown (Elwood et al. 1981) whereas N enrichment had no effect on leaf breakdown rate (Triska and Sedell 1976, Newbold et al. 1983). Evidence for stimulation of leaf breakdown by $\mathrm{N}$ has been obtained in a comparison of two streams that differed in nitrate concentrations (Meyer and Johnson 1983). Laboratory studies, in contrast to field studies, are typically carried out in closed systems in which nutrient amendments are made at the beginning of the study, and nutrients are not 
replenished as they are removed by microorganisms. For example, Howarth and Fisher (1976) found that nitrate concentrations of the water in their laboratory streams had decreased to low levels during the study. In such systems, differential depletion of nutrients may alter which nutrient becomes limiting.

Fungi, particularly aquatic hyphomycetes, have been demonstrated to be the microbial group responsible for the initial breakdown of leaves in streams (Suberkropp and Klug 1976, Findlay and Arsuffi 1989, Gessner and Chauvet 1994) and for modifying leaf detritus into a more suitable food source for invertebrate detritivores (Bärlocher 1985, Suberkropp 1992). The activities of stream fungi have recently been shown to be regulated by substrate quality, i.e., by internal chemical factors, particularly the lignin content of leaves (Gessner and Chauvet 1994). The effects of external chemical factors such as dissolved nutrients on the activities of stream fungi are not well understood (Chamier 1992). However, several studies have indicated that levels of microbial biomass and rates of sporulation by aquatic hyphomycetes are greater on leaves colonized in hardwater streams (high $\mathrm{pH}$ and alkalinity) with elevated concentrations of $\mathrm{N}$ and $\mathrm{P}$ than on leaves from hardwater streams with lower concentrations of nutrients or from softwater streams (Bärlocher 1982, Rosset et al. 1982, Suberkropp 1991). These observations suggest that fungal activity can also be controlled by external chemical factors in the water flowing across leaf surfaces.

Our overall hypothesis is that the chemistry of the water passing over leaf detritus affects the activity of fungi within the leaves and, consequently, the rate at which leaf detritus is broken down in streams. We used two approaches to examine the relationships among water chemistry, fungal activity, and leaf breakdown. First, we compared breakdown rates and fungal activity associated with yellow poplar (Liriodendron tulipifera L.) leaves decomposing in streams that differed in water chemistry. Diverse geological formations in Alabama give rise to streams that exhibit large differences in water chemistry even though they occur within a small geographical area (Ward et al. 1992). Consequently, one can find streams that differ in water chemistry, but that are generally similar with respect to other characteristics (e.g., climate, assemblages of trees in the riparian vegetation, and the timing and composition of leaf litter inputs). During the autumn of two consecutive years, we examined five hardwater streams that exhibited differences in nitrate concentrations but were similar with respect to other chemical parameters, and three softwater streams that contained low concentrations of both $\mathrm{N}$ and $\mathrm{P}$.

The second approach we used was to determine the response of the fungi associated with leaf detritus to changes in the chemistry of the water flowing over leaves. We did this by performing a reciprocal exchange experiment. Here, we placed leaves in two streams with contrasting water chemistries, allowed them to become colonized by microorganisms, and then exchanged the leaves between streams. We predicted that fungal activity and rates of leaf breakdown would be altered by the exchange, i.e., stimulated after transfer to the stream with higher nutrient concentrations or depressed after transfer to the stream with lower nutrient concentrations. During the subsequent breakdown of these leaves, we compared the changes in leaves that had been exchanged with those occurring in leaves that had remained in each of the streams for the entire time.

\section{METHODS \\ Study sites}

During 1989, studies were carried out in seven streams, and during 1990, studies were carried out in three streams. Two streams, Big Sandy and South Sandy, were common to studies in both years. All streams are first or second order and are located within $60 \mathrm{~km}$ of one another near the boundaries of the Coastal Plain, Appalachian Plateau, and Valley and Ridge physiographic provinces in west central Alabama. Rocky Branch, Little Schultz, and Cottingham are located in the Valley and Ridge Physiographic province. These streams have stream beds composed of limestone bedrock and cobble. All the remaining streams are in the Coastal Plain physiographic province. Big Sandy and Schultz are fed from springs in limestone bedrock and have bottoms containing sand, cobble, and limestone boulders. South Sandy and Mayfield have shifting sandy bottoms. Yellow Creek has a stream bed composed of sandstone bedrock and cobble. All flow through forested areas containing a high diversity of deciduous and evergreen tree species. Yellow poplar was found growing in the riparian vegetation of all study sites.

On each sampling date, stream water was collected and transported on ice to the laboratory for chemical analyses. Alkalinity was determined by titrating with $0.04 \mathrm{~mol} / \mathrm{L} \mathrm{H}_{2} \mathrm{SO}_{4}$, and $\mathrm{pH}$ was determined with a Ross combination electrode calibrated with Orion pure water calibration buffers. Aliquots of stream water were filtered through glass fiber filters (Whatman GF/F) and frozen. They were later thawed and concentrations of ammonium- $\mathrm{N}$, nitrate- $\mathrm{N}$, nitrite- $\mathrm{N}$, and phosphate-P determined with a Lachat flow injection analyzer. Concentrations of nitrite- $\mathrm{N}$ were always below or near detection limits and are not reported. Current velocity of the streams was determined with a Swoffer 2000 meter, and discharge was calculated on each sample date from current velocity and depth measurements taken at 0.5 $1 \mathrm{~m}$ intervals across each stream. Mean temperature between sample dates was determined by averaging values obtained from maximum-minimum thermometers placed in each stream. Concentrations and species composition of aquatic hyphomycete conidia in the wa- 
ter were determined by filtering $0.1-0.3 \mathrm{~L}$ of water per triplicate filter at streamside $(5 \mu \mathrm{m}$ pore size, $47-\mathrm{mm}$ diameter), fixing and staining with $0.01 \%$ trypan blue, and counting conidia in 100 fields/filter (Iqbal and Webster 1973).

\section{Stream studies}

Litter bags. - The sampling units in all studies were autumn-shed yellow poplar (Liriodendron tulipifera) leaves that were placed individually in fiberglass mesh bags $(14 \times 16 \mathrm{~cm}, 1.2 \mathrm{~mm}$ mesh). Bags were suspended in the current from strips of wood $(2 \times 4 \mathrm{~cm} \times 2.4$ $\mathrm{m})$ by monofilament line, and two wood strips were held parallel to the current by tying each end to concrete blocks. Three such groups of bags were placed in each stream (in three reaches) and bags removed from each reach were used as replicates. Feeding by invertebrate detritivores was virtually eliminated (with the exception of a few chironomid larvae in late stages of breakdown) in our studies by the small mesh size of litter bags and by suspending the bags off the stream bottom in the current. Suspending individual leaves in the current also enhanced the likelihood that effects caused by differences in nutrient concentration would be detected. The current velocity of the water passing across each set of bags was determined at the beginning of the study for each stream. Leaves were air dried and weighed prior to each study. Initial ash-free dry mass (AFDM) was determined at the beginning of the study by removing three bags from each stream immediately after they were placed in the stream, drying them at $60^{\circ} \mathrm{C}$ to a constant mass $(24-72 \mathrm{~h})$ and determining ash content after ignition at $550^{\circ} \mathrm{C}$ for $12-24 \mathrm{~h}$. Initial AFDM of the other leaf samples was calculated from their initial air-dried mass and the fraction lost from the leaves removed at $0 \mathrm{~d}$.

Analyses.-For the 1989 study, leaves were placed in the streams on 24 October (Schultz, Big Sandy, Little Schultz, and Cottingham) and 26 October (Yellow, Mayfield, and South Sandy). The 1990 study was begun on 30 October. Leaves were removed from streams at intervals ranging from $2 \mathrm{~d}$ to $3 \mathrm{wk}$. During the early part of the studies, sampling was more frequent. On each sampling date, 2-3 litter bags were removed from each replicate reach. The leaf from one litter bag was used to determine AFDM, the leaf from the second was used to determine leaf softness (1989 study), and the leaf from the other litter bag was used to cut leaf disks (25 disks, 11.4-mm diameter) to determine ATP concentration (5 disks from each replicate), sporulation rate of aquatic hyphomycetes (15 disks from each replicate), and leaf disk AFDM (5 disks from each replicate). To determine AFDM, leaves were rinsed to remove debris, dried at $60^{\circ} \mathrm{C}$, and ignited at $550^{\circ} \mathrm{C}$. During the 1989 study, leaf softness was determined with a penetrometer (Suberkropp and Klug 1980). Leaves were placed between two Plexiglas plates and the weight necessary to cause a 5-mm diameter rod to pen- etrate the leaf was determined. Major veins were avoided. To extract ATP, 5 disks from each replicate leaf were homogenized with cold $\mathrm{H}_{2} \mathrm{SO}_{4}(2.4 \mathrm{~mol} / \mathrm{L})$ containing oxalic acid $(8 \mathrm{~g} / \mathrm{L})$ with a Polytron (Brinkmann) homogenizer for $15 \mathrm{~s}$, centrifuged, filtered, neutralized, and frozen (Suberkropp et al. 1983). ATP was later determined with a Turner Luminometer, and values reported have been corrected on the basis of internal standards. To determine sporulation rates of aquatic hyphomycetes, 15 disks from each replicate leaf were placed in aeration chambers (Suberkropp 1991) with $40 \mathrm{~mL}$ filtered water from the stream in which the leaves had been removed. These disks were aerated (100 $\mathrm{mL}$ air/min) for $24 \mathrm{~h}$ after which two aliquots of the fluid were filtered (5- $\mu \mathrm{m}$ pore size, $25-\mathrm{mm}$ diameter), stained with $0.1 \%$ trypan blue in lactic acid and examined microscopically. Number and species of conidia on filters were determined so that sporulation rates of fungi could be calculated. Five disks from each replicate leaf were also dried at $60^{\circ} \mathrm{C}$ and ignited at $550^{\circ} \mathrm{C}$ to determine AFDM per disk.

Exchange experiments.-During the study carried out in 1990, leaves were exchanged between a hardwater stream with relatively high nutrient concentrations (Big Sandy) and a softwater stream with low nutrient concentrations (South Sandy) after they had been submerged in these streams for $9 \mathrm{~d}$, i.e., the time necessary to allow the establishment of fungal communities during the study conducted in 1989. Those leaves colonized initially in Big Sandy and transported to South Sandy are referred to as South Sandy exchange and those colonized initially in South Sandy are called Big Sandy exchange. These leaves were sampled in the manner described above.

\section{Statistical analyses}

Breakdown rate $(k)$ was calculated by nonlinear regression analysis using the model, $m_{t}=m_{0} e^{-k t}$, where $m_{t}$ is AFDM remaining at time, $t$, in days or degreedays, $m_{0}$ is the initial AFDM at the beginning of the study (see Chauvet 1987). The regressions of leaf breakdown have been corrected for initial leaching losses in the first $2 \mathrm{~d}$ by considering the $2-\mathrm{d}$ point as the initial theoretical value of the model. Insofar as this nonlinear regression and linear regression of $1 n$ transformed data gave quite similar results, differences in $k$ determined from $\ln$ transformed data were detected by analysis of covariance (ANCOVA) followed by Tukey's comparison (Zar 1984). Similar calculations were carried out for breakdown rate calculated on a degreeday basis and for rate of leaf softening $(p)$. Correlation analyses were used to examine relationships between breakdown rates, maximum ATP concentrations, maximum sporulation rates, nitrate concentrations, phosphate concentrations, and mean temperatures using Bonferroni's procedure to calculate significance levels. Multiple regressions were carried out with breakdown rates, maximum ATP concentrations, or maximum 
TABLE 1. Chemical and physical characteristics of the streams. Numbers represent means with ranges given in parentheses.

\begin{tabular}{lccccc}
\hline \hline \multicolumn{1}{c}{ Stream (year) } & $\begin{array}{c}\text { Ammonium-N } \\
(\mu \mathrm{g} / \mathrm{L})\end{array}$ & $\begin{array}{c}\text { Nitrate-N } \\
(\mu \mathrm{g} / \mathrm{L})\end{array}$ & $\begin{array}{c}\text { Phosphate-P } \\
(\mu \mathrm{g} / \mathrm{L})\end{array}$ & $\begin{array}{c}\text { Alkalinity. } \\
(\mathrm{mmol} / \mathrm{L})\end{array}$ & $\mathrm{pH}$ \\
\hline Hardwater & & & & & \\
$\quad$ Schultz (1989) & $15(7-42)$ & $298(207-350)$ & $76(73-80)$ & $2.06(1.28-2.51)$ & $8.1(8.0-8.3)$ \\
Big Sandy (1989) & $9(0-50)$ & $252(185-294)$ & $92(86-97)$ & $2.19(1.58-2.52)$ & $8.1(8.0-8.2)$ \\
Big Sandy (1990) & $9(0-53)$ & $260(247-267)$ & $80(75-84)$ & $2.48(2.38-2.58)$ & $8.0(7.9-8.1)$ \\
Rocky Branch (1990) & $12(0-56)$ & $93(60-109)$ & $67(63-70)$ & $2.33(2.03-2.40)$ & $8.1(8.0-8.2)$ \\
Little Schultz (1989) & $11(0-20)$ & $59(28-94)$ & $58(45-67)$ & $1.99(0.72-2.94)$ & $8.1(7.7-8.3)$ \\
Cottingham (1989) & $12(0-48)$ & $18(5-32)$ & $77(64-98)$ & $3.17(2.83-3.38)$ & $8.3(8.1-8.6)$ \\
Softwater & & & & & \\
Yellow (1989) & $7(0-24)$ & $24(1-43)$ & $8(5-16)$ & $0.07(0.06-0.08)$ & $6.1(6.0-6.2)$ \\
Mayfield (1989) & $14(5-35)$ & $8(2-15)$ & $9(6-13)$ & $0.09(0.07-0.12)$ & $6.2(5.9-6.4)$ \\
South Sandy (1989) & $14(0-22)$ & $6(3-8)$ & $9(5-13)$ & $0.10(0.07-0.12)$ & $6.4(6.0-6.7)$ \\
South Sandy (1990) & $25(0-72)$ & $7(2-14)$ & $11(6-16)$ & $0.10(0.08-0.12)$ & $6.2(5.8-6.5)$ \\
\hline
\end{tabular}

sporulation rates as dependent variables and temperature, nitrate, and phosphate concentrations as independent variables. The independent variables in these regressions were evaluated by comparison of $t$ values and by forward stepwise regression (Zar 1984). These analyses were based on mean values using data from all streams examined in both years.

The seven streams examined in 1989 were divided to represent three sets of streams and examined with one-way analyses of variance (ANOVA) to detect differences among streams exhibiting different characteristics. In these analyses, values from the following streams were used as replicates: large hardwater, highest nitrate concentrations-Schultz and Big Sandy; small hardwater, low nitrate concentrations-Little Schultz and Cottingham; softwater, low nitrate concentrations-Mayfield, South Sandy, and Yellow. Multiple comparisons (Bonferroni) were used to determine differences among means.

Values of $P<0.05$ were considered significant in all cases. Statistical calculations were made using Systat computer software (Wilkinson 1990).

\section{RESULTS}

\section{Stream characteristics}

The streams we examined can be divided into two groups based on $\mathrm{pH}$ and alkalinity (Table 1). Schultz, Big Sandy, Rocky Branch, Little Schultz, and Cottingham are all hardwater streams with moderate alkalinity (0.7-3.4 mmol/L) and basic $\mathrm{pH}$ (7.7-8.6). Yellow, Mayfield, and South Sandy are softwater streams with low alkalinity $(0.06-0.12 \mathrm{mmol} / \mathrm{L})$ and acidic $\mathrm{pH}(5.8-$ 6.7). The streams also can be divided on the basis of size, i.e., discharge (Table 1). Three hardwater streams (Rocky Branch, Little Schultz, and Cottingham) had lower discharge than the softwater streams and the other two hardwater streams (Schultz and Big Sandy). In 1989 , current velocity across the leaves in the two small hardwater streams (Little Schultz and Cottingham) was less than in the larger streams (Table 1). However, in 1990, we placed leaves in narrow sections of Rocky Branch so that the current velocity across leaves was similar to that observed in the larger streams. Discharge and current velocity across the leaves in both Big Sandy and South Sandy were less and temperatures were higher during 1990 than during 1989.

Since the hardwater streams are spring fed, they exhibited higher temperatures than the softwater streams during the period (autumn-early winter) of these studies. The two large hardwater streams, Schultz and Big Sandy, exhibited less variation in temperature than the other streams. The streams also differed with respect to the concentrations of nitrate and phosphate (Table 1). Phosphate concentrations in the hardwater streams were similar and were considerably higher than those in the softwater streams. There were large differences in nitrate concentration, with the two large hardwater streams (Schultz and Big Sandy) exhibiting the highest concentrations of nitrate. The softwater streams had low concentrations of nitrate, and the nitrate concentration of one hardwater stream, Cottingham, was similar to that of the softwater streams.

\section{Fungal activity and leaf breakdown}

Rates $(k)$ of yellow poplar leaf breakdown differed among the streams (Table 2) with the highest rates occurring in the larger hardwater streams (Schultz and Big Sandy). The percent AFDM remaining for leaves in the streams is presented in Figs. 1 (1989 study and Rocky Branch) and 2 (South Sandy and Big Sandy in 1990). Rates of breakdown of yellow poplar leaves from all streams exhibited significant positive correlations with nitrate concentrations, phosphate concentrations, and temperature, but only nitrate concentrations were significantly correlated with $k$ when hardwater streams were analyzed separately (Table 3). When nitrate concentrations, phosphate concentrations, and temperature from all streams were used as independent variables in a multiple regression, only nitrate concentration had a significant effect on $k$ (evaluation of $t$ values or stepwise multiple regression, Zar 1984). In addition, when breakdown rates were calculated on a degree-day basis, the same pattern of differences among streams was noted (Table 2). 
TABle 1. Continued.

\begin{tabular}{ccc}
\hline \hline $\begin{array}{c}\text { Temperature } \\
\left({ }^{\circ} \mathrm{C}\right)\end{array}$ & \multicolumn{1}{c}{$\begin{array}{c}\text { Discharge } \\
\left(\mathrm{m}^{3} / \mathrm{s}\right)\end{array}$} & \multicolumn{1}{c}{$\begin{array}{c}\text { Velocity } \\
(\mathrm{m} / \mathrm{s})\end{array}$} \\
\hline & & \\
$13.4(8-19)$ & $0.41(0.30-0.78)$ & $0.26(0.23-0.27)$ \\
$13.4 \cdot(11-18)$ & $0.63(0.51-0.93)$ & $0.49(0.36-0.69)$ \\
$16.2(13-18)$ & $0.48(0.40-0.55)$ & $0.26(0.24-0.28)$ \\
$13.4(8-19)$ & $0.03(0.02-0.05)$ & $0.23(0.15-0.36)$ \\
$11.8(7-19)$ & $0.05(0.004-0.29)$ & $0.05(0.003-0.05)$ \\
$12.1(6-18)$ & $0.05(0.03-0.16)$ & $0.16(0.003-0.45)$ \\
& & \\
$10.6(4-18)$ & $0.39(0.14-1.36)$ & $0.25(0.10-0.36)$ \\
$9.8(1-19)$ & $0.33(0.11-0.52)$ & $0.22(0.10-0.32)$ \\
$9.5(1-17)$ & $0.49(0.24-0.79)$ & $0.26(0.24-0.29)$ \\
$11.6(5-18)$ & $0.29(0.11-0.89)$ & $0.10(0.08-0.12)$ \\
\hline
\end{tabular}

Leaves were softened at faster rates in the large hardwater streams (Schultz and Big Sandy) than in other streams (Fig. 3, Table 2). Rates of softening did not differ significantly between the two small hardwater streams and the softwater streams. However, penetrometer readings of leaves in the softwater streams plateaued at $\approx 100 \mathrm{~g}$ and leaves did not become softer throughout the remainder of the study (Fig. 3).

In the large hardwater streams (Schultz and Big Sandy), ATP concentration associated with leaves rapidly increased and then declined (Figs. 4 and 5). Rate of increase and maximum level of ATP were higher in these streams than in other streams. Leaves in the small hardwater streams (Little Schultz, Cottingham, and Rocky Branch) exhibited gradual increases in ATP concentration throughout the study. Leaves in the softwater streams exhibited the lowest maximum ATP concentration, which typically occurred in the first $2-3 \mathrm{wk}$ after leaves were submerged. Maximum ATP concentration associated with leaves decomposing in all the streams was correlated with nitrate concentration, phosphate concentration, and temperature (Table 3). When hardwater streams were analyzed separately, only nitrate concentration and temperature were sig-

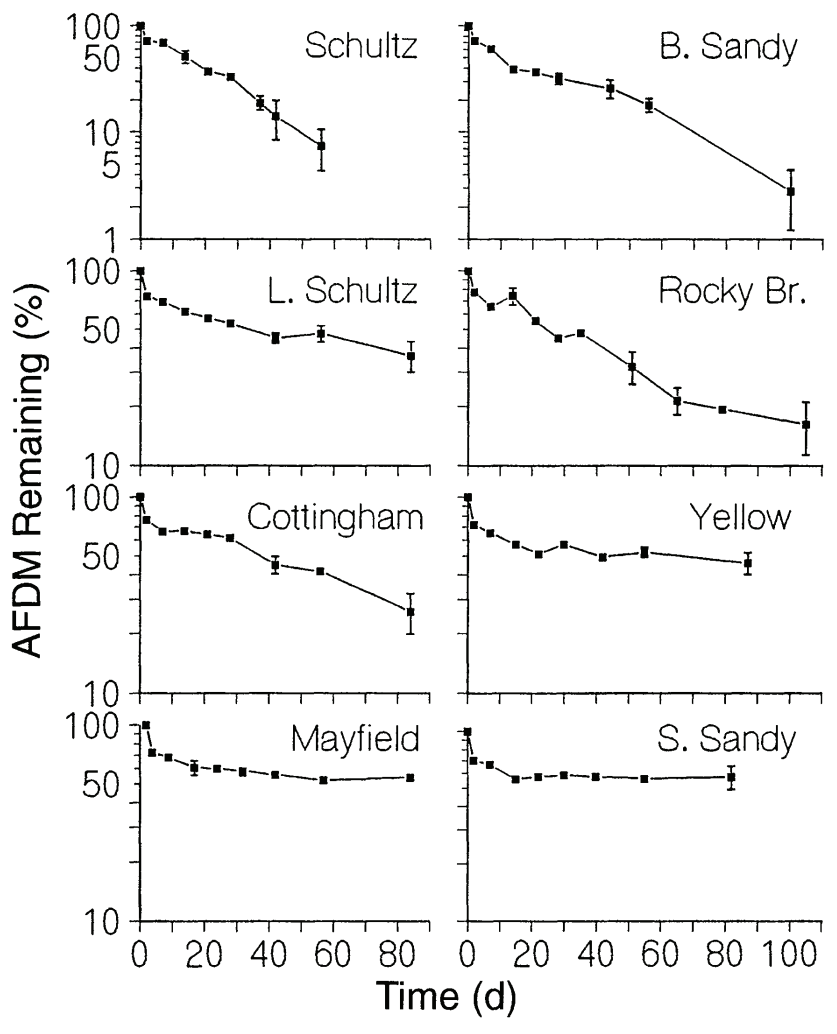

Fig. 1. Ash-free dry mass (AFDM) of yellow poplar leaves remaining in the eight streams examined. All data were collected in 1989, except those from Rocky Branch (1990). Note differences in scale between the top two graphs and the rest. Symbols indicate mean with vertical bars indicating \pm 1 standard error, $n=3$.

nificantly correlated with maximum ATP concentration (Table 3). In multiple regressions using data from all streams, only nitrate concentration had significant effects on maximum ATP concentration based on $t$ values, but none of the three variables was eliminated in stepwise regression.

Sporulation rates of aquatic hyphomycetes were also highest from leaves colonized in the large hardwater streams (Figs. 6 and 7). Leaves colonized in Yellow

TABLE 2. Breakdown rates $(k)$ based on days and degree days and softening rates $(p)$ of yellow poplar leaves placed in the streams.

\begin{tabular}{|c|c|c|c|c|c|c|}
\hline \multirow[b]{2}{*}{ Stream (year) } & \multicolumn{4}{|c|}{ Breakdown rates $(k)$} & \multicolumn{2}{|c|}{ Softening rates $(p)$} \\
\hline & $k\left(d^{-1}\right) \pm 95 \% \mathrm{CI}^{*}$ & $r^{2}$ & $k\left(\text { degree } d^{-1}\right)^{*}$ & $r^{2}$ & $p\left(d^{-1}\right)^{*}$ & $r^{2}$ \\
\hline \multicolumn{7}{|l|}{ Hardwater } \\
\hline Schultz (1989) & $0.0342 \pm 0.0049 \mathrm{a}$ & 0.97 & $0.0022 \pm 0.0003 \mathrm{a}$ & 0.96 & $0.239 \pm 0.061 \mathrm{a}$ & 0.76 \\
\hline Big Sandy (1989) & $0.0321 \pm 0.0054 \mathrm{a}$ & 0.96 & $0.0020 \pm 0.0002 \mathrm{a}$ & 0.96 & $0.189 \pm 0.048 \mathrm{a}$ & 0.91 \\
\hline Big Sandy (1990) & $0.0258 \pm 0.0039 \mathrm{~b}$ & 0.96 & $0.0016 \pm 0.0001 \mathrm{~b}$ & 0.96 & & \\
\hline Rocky Branch (1990) & $0.0175 \pm 0.0024 \mathrm{~b}$ & 0.97 & $0.0013 \pm 0.0001 \mathrm{~b}$ & 0.97 & & \\
\hline Little Schultz (1989) & $0.0100 \pm 0.0017 \mathrm{~cd}$ & 0.99 & $0.0008 \pm 0.0001 \mathrm{~cd}$ & 0.99 & $0.068 \pm 0.010 \mathrm{~b}$ & 0.95 \\
\hline Cottingham (1989) & $0.0117 \pm 0.0017 \mathrm{bc}$ & 0.99 & $0.0009 \pm 0.0001 \mathrm{bcd}$ & 0.99 & $0.053 \pm 0.014 \mathrm{~b}$ & 0.93 \\
\hline \multicolumn{7}{|l|}{ Softwater } \\
\hline Yellow (1989) & $0.0074 \pm 0.0019 \mathrm{de}$ & 0.98 & $0.0007 \pm 0.0001 \mathrm{~d}$ & 0.96 & $0.051 \pm 0.012 b$ & 0.90 \\
\hline Mayfield (1989) & $0.0057 \pm 0.0013 \mathrm{de}$ & 0.99 & $0.0005 \pm 0.0001 \mathrm{~d}$ & 0.99 & $0.070 \pm 0.019 \mathrm{~b}$ & 0.81 \\
\hline South Sandy (1989) & $0.0042 \pm 0.0018 \mathrm{e}$ & 0.99 & $0.0004 \pm 0.0001 \mathrm{~d}$ & 0.99 & $0.068 \pm 0.021 \mathrm{~b}$ & 0.81 \\
\hline South Sandy (1990) & $0.0036 \pm 0.0011 \mathrm{e}$ & 0.99 & $0.0003 \pm 0.0001 \mathrm{~d}$ & 0.99 & & \\
\hline
\end{tabular}

\footnotetext{
* Different letters indicate significant $(P<0.05)$ differences between rates (ANCOVA, Tukey's comparison).
} 


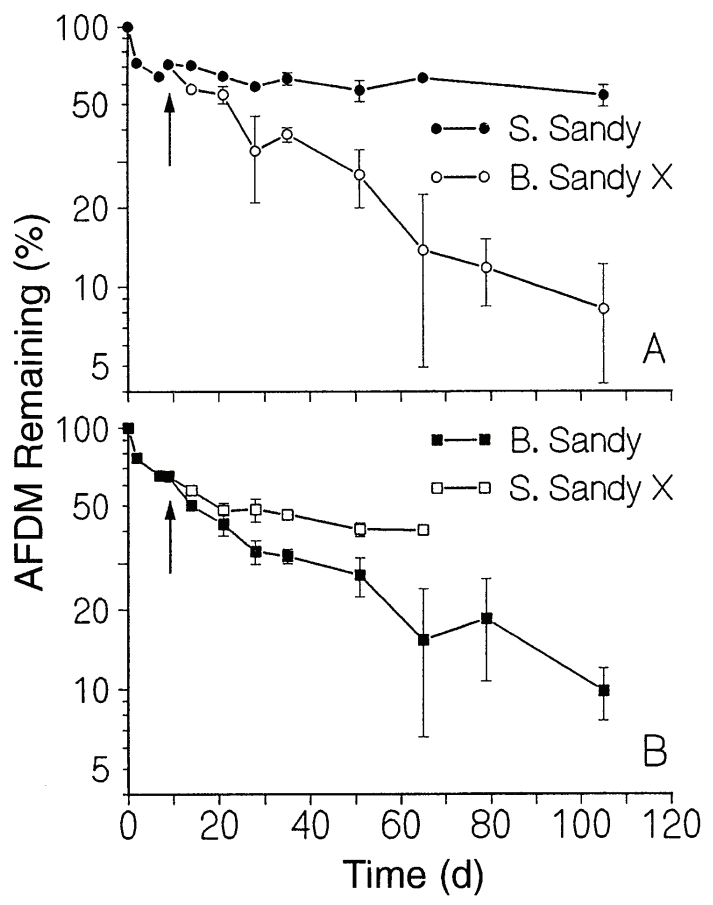

FIG. 2. Ash-free dry mass (AFDM) of yellow poplar leaves remaining in: (A) South Sandy and Big Sandy exchange (B. Sandy X); (B) Big Sandy and South Sandy exchange (S. Sandy $X$ ) treatments during the study carried out in 1990. Symbols indicate mean with vertical bars indicating \pm 1 standard error, $n=3$. Arrows indicate the time that leaves were exchanged.

Creek and Rocky Branch exhibited intermediate sporulation rates, and leaves from the other streams generally exhibited low sporulation rates. Maximum sporulation rate was correlated with nitrate concentration and temperature but not phosphate concentration when all streams were included (Table 3 ). Only nitrate concentration was correlated with maximum sporulation rate in analyses of hardwater streams. When both ni-

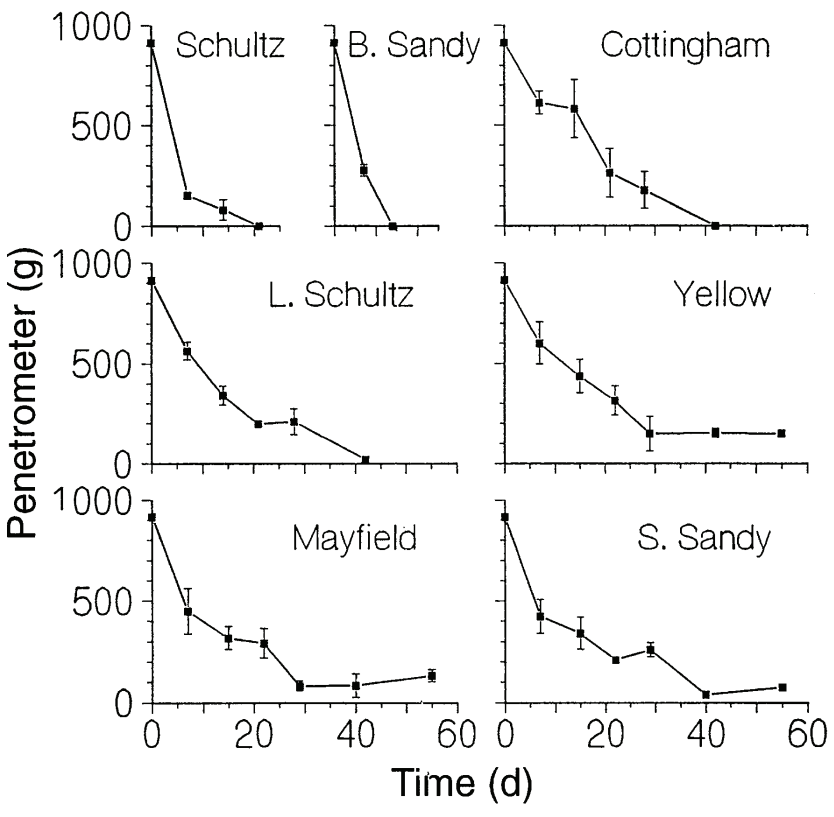

FIG. 3. Relative softness of yellow poplar leaves in the seven streams examined in 1989 as indicated by penetrometer measurements. Symbols indicate mean with vertical bars indicating \pm 1 standard error, $n=3$.

trate concentration and temperature were used as independent variables in multiple regression of all streams, only nitrate had significant effects on maximum sporulation rates (based on $t$ values and stepwise regression).

The design of the 1989 study allowed us to analyze these data using streams rather than litter bags within each stream as replicates. Differences among streams were then assessed with ANOVA. These analyses indicated that the breakdown rates of yellow poplar leaves $(F=176.2, P=0.0001)$, maximum ATP concentration $(F=114.9, P=0.0003)$, maximum spor-

TABLE 3. Pearson correlation coefficients and partial correlation coefficients obtained in stepwise multiple regression analysis (in parentheses) among environmental variables and changes in leaves decomposing in streams.

\begin{tabular}{|c|c|c|c|}
\hline & {$\left[\mathrm{NO}_{3}-\mathrm{N}\right]$} & {$\left[\mathrm{PO}_{4}-\mathrm{P}\right]$} & Temperature \\
\hline \multicolumn{4}{|l|}{ All streams $(n=10)$} \\
\hline \multicolumn{4}{|l|}{ Stream characteristics } \\
\hline $\begin{array}{l}{\left[\mathrm{NO}_{3}-\mathrm{N}\right]} \\
{\left[\mathrm{PO}_{4}-\mathrm{P}\right]}\end{array}$ & $\begin{array}{l}\cdots \\
\cdots\end{array}$ & $\begin{array}{l}0.75 \\
\cdots\end{array}$ & $\begin{array}{l}0.80 \\
0.81\end{array}$ \\
\hline \multicolumn{4}{|l|}{ Leaf characteristics } \\
\hline$-k$ & 0.97 & $0.83(0.66)$ & 0.77 NS* $(-0.04)$ \\
\hline Max. [ATP] & 0.95 & $0.86(0.60)$ & 0.91 \\
\hline Max. sporulation rate $(n=9)$ & 0.90 & $0.46 \mathrm{NS}(-0.48)$ & $0.72 \mathrm{NS}(-0.01)$ \\
\hline \multicolumn{4}{|l|}{ Hardwater streams $(n=6)$} \\
\hline \multicolumn{4}{|l|}{ Stream characteristics } \\
\hline$\left[\mathrm{NO}_{3}-\mathrm{N}\right]$ & $\cdots$ & $0.60 \mathrm{NS}$ & $0.67 \mathrm{NS}$ \\
\hline$\left[\mathrm{PO}_{4}-\mathrm{P}\right]$ & $\cdots$ & $\cdots$ & $0.42 \mathrm{NS}$ \\
\hline \multicolumn{4}{|l|}{ Leaf characteristics } \\
\hline$-k$ & 0.96 & $0.75 \mathrm{NS}$ & $0.51 \mathrm{NS}$ \\
\hline $\operatorname{Max} .[\mathrm{ATP}]$ & 0.92 & $0.70 \mathrm{NS}$ & 0.84 \\
\hline Max. sporulation rate $(n=5)$ & 0.97 & $0.66 \mathrm{NS}$ & $0.85 \mathrm{NS}$ \\
\hline
\end{tabular}

\footnotetext{
$*$ NS $=$ not significant.
} 


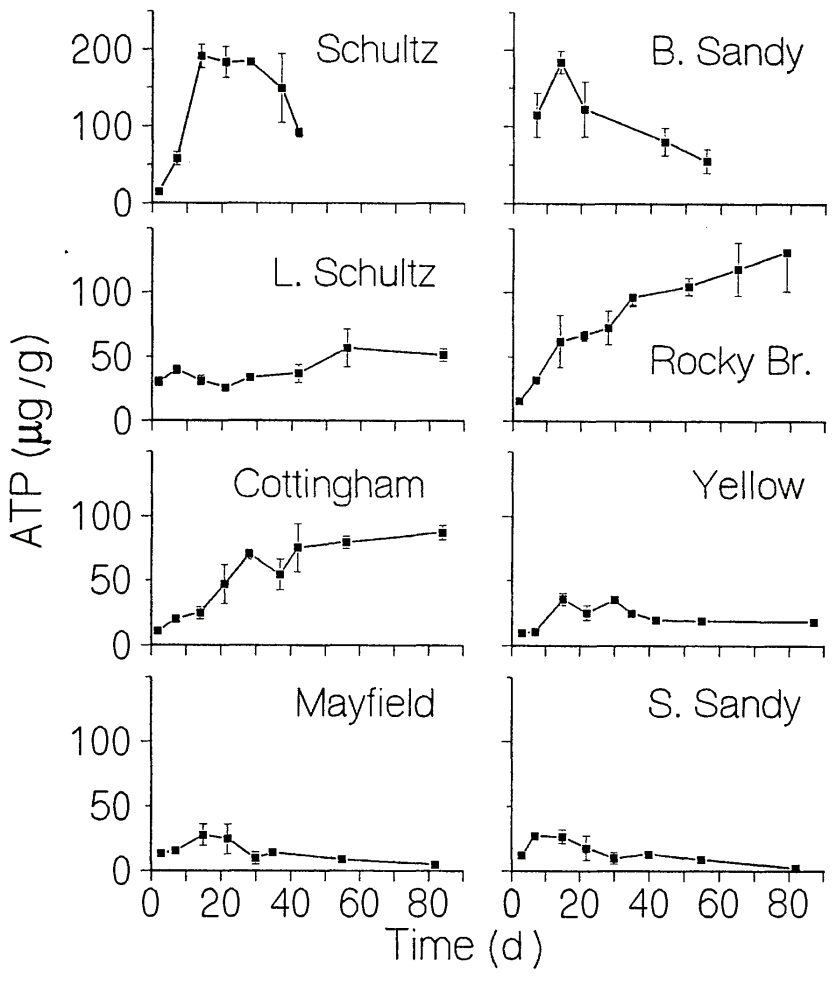

FIG. 4. Concentrations of ATP associated with yellow poplar leaves decomposing in the eight streams examined. All data were collected in 1989, except those from Rocky Branch (1990). Note differences in scale between the top two graphs and the rest. Symbols indicate mean with vertical bars indicating \pm 1 standard error, $n=3$.

ulation rate $(F=14.5, P=0.015)$, and rate of softening $(F=41.8, P=0.002)$ differed among the streams. Leaves in the large hardwater streams (Schultz and Big Sandy) exhibited faster breakdown rates, faster softening rates, higher ATP concentrations, and higher sporulation rates than leaves in the other streams. However, leaves placed in the small hardwater and the softwater streams did not differ with respect to any of these parameters except maximum ATP concentrations. The maximum ATP concentrations of leaves in the small hardwater streams were higher than those found in the softwater streams.

The species composition of the aquatic hyphomycete community growing on yellow poplar leaves differed almost completely between the hardwater and softwater streams (Table 4). Major species in the hardwater streams included Lunulospora curvula, Tetracladium marchalianum, and Clavatospora tentacula. Nitrate concentrations of the hardwater streams did not appear to play a major role in determining community composition. However, in two of the small hardwater streams, Alatospora acuminata was present in high abundance. With the exception of $L$. curvula, the major species detected in the hardwater streams were not seen in the softwater streams. In two of the softwater streams (Mayfield and South Sandy), Anguillospora filiformis was the dominant species and the number of species colonizing leaves was extremely low. In the other soft- water stream (Yellow Creek), Flagellospora curvula and Crucella subtilis, a mycoparasite, were the major species. Of the species occurring in the softwater streams, only A. filiformis was observed in the hardwater streams.

The fungal community developing on leaves was similar in species composition to the fungal spora being transported in the water (Table 5). Lunulospora curvula was the dominant species present as conidia in transport in hardwater streams and A. filiformis was dominant in softwater streams. Several species (e.g., C. tentacula, T. marchalianum), which were dominant on the leaves we examined, did not constitute a major percentage of the spora. The large hardwater streams generally had higher concentrations of conidia in transport than the other streams, but differences among streams were not large.

Exchange experiment.-After leaves were exchanged between Big Sandy and South Sandy during the study carried out in 1990, the microbial community responded rapidly (Figs. 2, 5, 7). Leaves transported from Big Sandy (hard water, high nutrient concentrations) to South Sandy (soft water, low nutrient concentrations) exhibited decreased breakdown rates (S. Sandy X, Fig. 2B). The ATP concentrations and rates of spore production also declined dramatically within the first $5 \mathrm{~d}$ after the exchange (S. Sandy X, Figs. 5B and 7B). Conversely, breakdown rates for leaves from

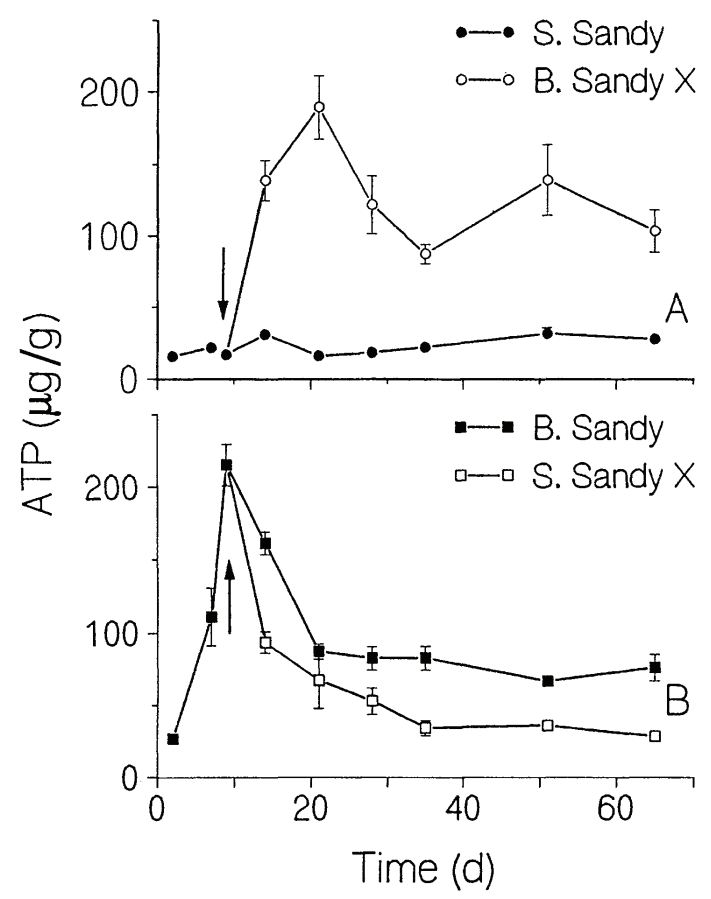

FIG. 5. Concentrations of ATP associated with yellow poplar leaves decomposing in: (A) South Sandy and Big Sandy exchange (B. Sandy X); (B) Big Sandy and South Sandy exchange (S. Sandy X) treatments during the study carried out in 1990. (Data for Big Sandy are taken from Suberkropp et al. 1993 and are included for comparative purposes.) Symbols indicate mean with vertical bars indicating \pm 1 standard error, $n=3$. Arrows indicate the time that leaves were exchanged. 


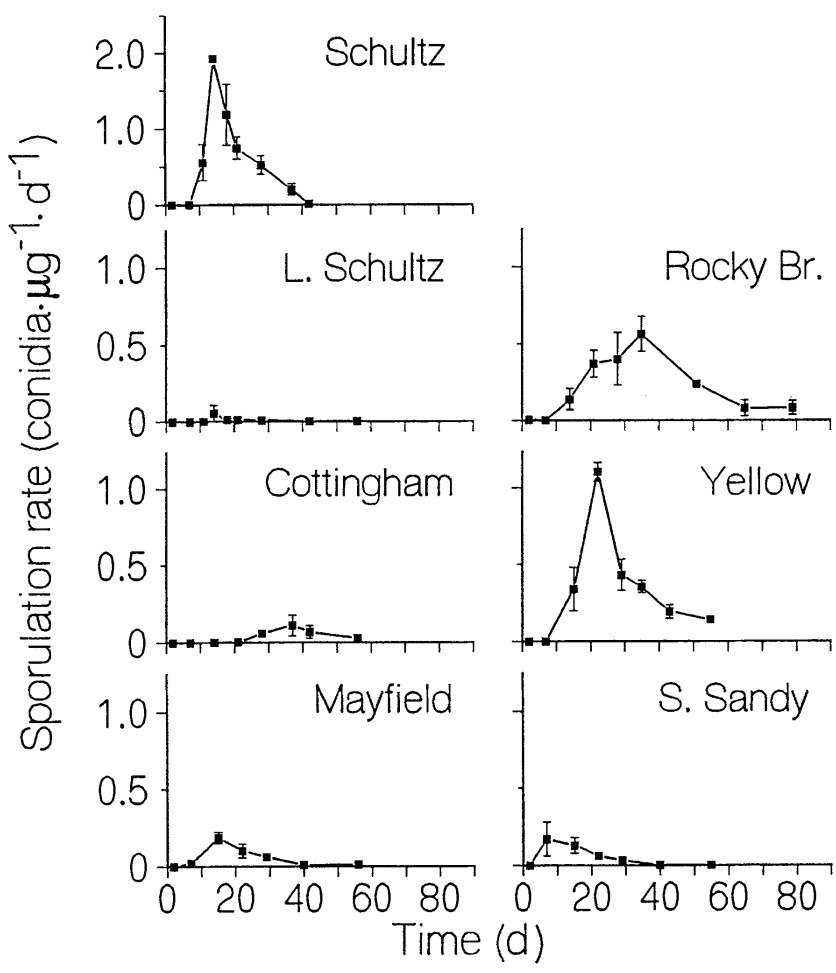

FIG. 6. Sporulation rates (number of conidia per microgram of leaf per day) of aquatic hyphomycetes associated with yellow poplar leaves decomposing in seven of the eight streams examined. A complete sporulation data set was not available in 1989 for Big Sandy. All data were collected in 1989, except those from Rocky Branch (1990). Note difference in scale between Schultz and the rest. Symbols indicate mean with vertical bars indicating \pm 1 standard error, $n=3$.

South Sandy that were placed in Big Sandy increased and became similar to those of leaves in Big Sandy (B. Sandy X, Fig. 2A). ATP concentrations increased dramatically during the first $5 \mathrm{~d}$ that leaves from South Sandy spent in Big Sandy (B. Sandy X, Fig. 5A). Sporulation rates also increased, but they never reached the rates exhibited by leaves that remained in Big Sandy the entire time (B. Sandy X, Fig. 7A). The species composition of the fungi sporulating on leaves from both the Big Sandy exchange and the South Sandy exchange treatments (Table 6) was similar to that found on leaves from Big Sandy (compare with Table 4). These results indicate that there was little species replacement on leaves transferred to South Sandy, but almost entire species replacement on leaves transferred to Big Sandy.

\section{DisCUSSION}

In the present study, the rates of leaf breakdown, microbial biomass, and rates of fungal sporulation varied greatly depending on the stream in which the leaves were placed. Variation in breakdown coefficients of yellow poplar leaves was $>9$-fold, and variation in maximum ATP concentrations associated with the leaves was as high as 8-fold in the different streams. The greatest difference among the streams was the maximum sporulation rate of aquatic hyphomycetes growing on leaves. Here, the variation was $>80$-fold. For comparison, Gessner and Chauvet (1994) reported variation associated with breakdown rates, fungal biomass (ergosterol concentrations) and sporulation rates among seven deciduous leaf species (ash to sycamore and oak) during breakdown in one stream to be 12.5; 2.5; and 10-fold, respectively. Based on differences in breakdown rates, yellow poplar leaves in the streams we examined can be placed over the entire processing continuum (i.e., from fast to slow leaf species) described by Petersen and Cummins (1974).

Nitrate concentrations, phosphate concentrations, and temperature of the streams examined in the present study were positively correlated (Table 3 ). The streams varied with respect to these variables in a manner consistent with the differences observed in fungal activity and leaf breakdown, i.e., higher decomposer activity generally occurred in the streams with higher concentrations of both nutrients and the higher temperatures. We have experimental evidence from laboratory microcosms that increasing the concentrations of either nitrate or phosphate can increase fungal activity on leaves (K. Suberkropp, unpublished data), and higher temperatures have been shown to increase rates of leaf breakdown in streams (Suberkropp et al. 1975, Webster and Benfield 1986, McArthur et al. 1988). However, several lines of evidence indicate that the differences in fungal activity and leaf breakdown we observed among streams were primarily due to the differences in nitrate concentrations exhibited by these streams.

When only the hardwater streams were included in

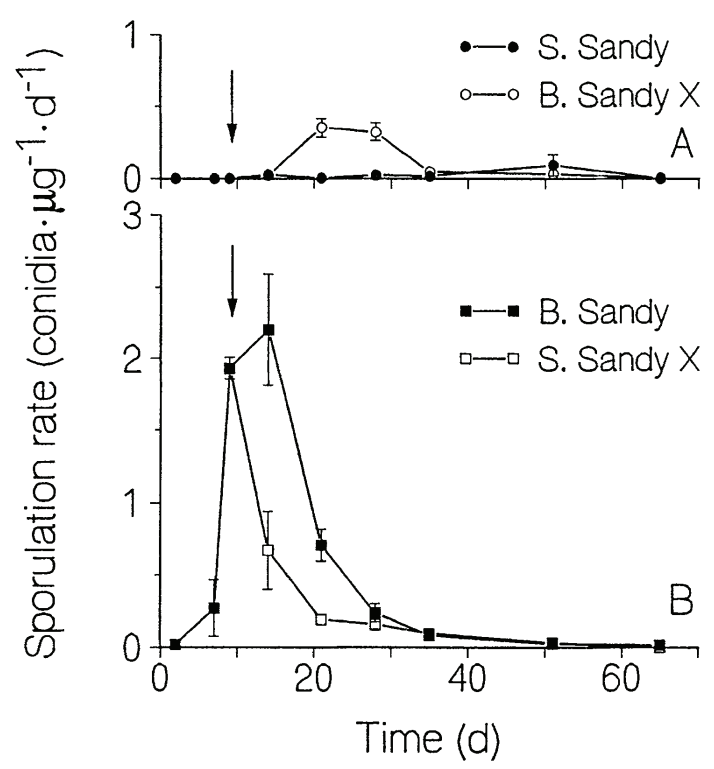

FIG. 7. Sporulation rates (number of conidia per microgram of leaf per day) of aquatic hyphomycetes associated with yellow poplar leaves decomposing in: (A) South Sandy and Big Sandy exchange (B. Sandy X); (B) Big Sandy and South Sandy (S. Sandy $\mathrm{X}$ ) exchange treatments during the study carried out in 1990. (Data for Big Sandy are taken from Suberkropp et al. 1993 and are included for comparative purposes.) Symbols indicate mean with vertical bars indicating \pm 1 standard error, $n=3$. Arrows indicate the time that leaves were exchanged. 
TABLE 4. Fungal community composition on yellow poplar leaves. Numbers represent percentages of the conidia produced on the date of maximum sporulation rate. Species indicated with + were detected on leaves in the stream at other sampling dates.

\begin{tabular}{|c|c|c|c|c|c|c|c|c|c|c|}
\hline \multirow[b]{2}{*}{ Fungal species } & \multicolumn{6}{|c|}{ Hardwater streams } & \multicolumn{4}{|c|}{ Softwater streams } \\
\hline & Schultz & $\begin{array}{c}\text { B. } \\
\text { Sandy } \\
89^{*}\end{array}$ & $\begin{array}{c}\text { B. } \\
\text { Sandy } \\
90\end{array}$ & $\begin{array}{l}\text { Rocky } \\
\text { Branch }\end{array}$ & $\begin{array}{c}\text { Little } \\
\text { Schultz }\end{array}$ & $\begin{array}{l}\text { Cot- } \\
\text { ting- } \\
\text { ham }\end{array}$ & Yellow & $\begin{array}{l}\text { May- } \\
\text { field }\end{array}$ & $\begin{array}{c}\text { S. } \\
\text { Sandy } \\
89\end{array}$ & $\begin{array}{c}\text { S. } \\
\text { Sandy } \\
90\end{array}$ \\
\hline Lunulospora curvula Ingold & 47 & 25 & 11 & 27 & 96 & + & 0.2 & & & + \\
\hline Tetracladium marchalianum de Wild. & 36 & 11 & 9 & 19 & 2 & 10 & & & & \\
\hline Clavatospora tentacula (Umphlett) Nilsson & 13 & 50 & 41 & 3 & 1 & & & & & \\
\hline Triscelophorus konajensis Sridhar \& Kaveriappa & 1 & 6 & 36 & 4 & & 1 & & + & & \\
\hline Alatospora acuminata Ingold & + & & + & 20 & 1 & 87 & 0.2 & & & \\
\hline Campylospora chaetocladia Ranzoni & 0.2 & 6 & + & 19 & + & & & & & \\
\hline Clavariopsis aquatica de Wild. & 1 & 3 & 2 & 1 & & & & & & \\
\hline Flagellospora penicillioides Ingold & 2 & & 1 & 1 & + & & & & & \\
\hline Sigmoidea prolifera Petersen (Crane) & & & + & 6 & & & & & & \\
\hline Tricladium chaetocladium Ingold & + & + & 0.5 & & & & + & & & \\
\hline Tetrachaetum elegans Ingold & & & & 0.2 & & + & 0.1 & & & \\
\hline Articulospora tetracladia Ingold & & & & & & & + & & & \\
\hline Crucella subtilis Marvanová \& Suberkropp & & & & & & & 17 & & & \\
\hline Anguillospora filiformis Greathead & + & 0.4 & & + & & & 1 & 94 & 97 & 100 \\
\hline Flagellospora curvula Ingold & & & & & & & 82 & 7 & 3 & \\
\hline
\end{tabular}

* Community composition after $14 \mathrm{~d}$.

correlation analyses, nitrate concentration was the only variable that significantly correlated with all measures of fungal activity and leaf breakdown (temperature was also significantly correlated with ATP concentration) (Table 3). In multiple regressions using data from all streams, nitrate concentration had a significant effect on measures of fungal activity and rate of leaf breakdown whereas temperature and phosphate concentration did not (an exception was that temperature did significantly affect maximum ATP concentrations). Moreover, differences in rate of breakdown of leaves in the different streams remained significant when they were calculated on a degree-day basis to account for temperature differences among streams. In addition, the streams we examined exhibited low atomic ratios of inorganic $\mathrm{N}: \mathrm{P}$ in the water suggesting potential $\mathrm{N}$ limitation. In the hardwater streams, N:P ratios ranged from 0.9 in Cottingham to a high value of only 9.3 in Schultz. Although the softwater streams contained much lower increases of both $\mathrm{N}$ and $\mathrm{P}$ than the hardwater streams, they exhibited similar atomic ratios of $\mathrm{N}: \mathrm{P}$ (i.e., 4-9). Our results support the conclusion that nitrogen was the limiting element in these streams since higher concentrations of nitrate in streams led to greater fungal activity associated with decomposing leaves and greater rates of leaf breakdown. Higher fungal activity may be possible, since streams in other regions can contain higher concentrations of nitrate than occurred in the streams we studied. For example, Bärlocher (1982) found maximum sporulation rates of 3 conidia $\mu \mathrm{g}^{-1} \cdot \mathrm{d}^{-1}$ on oak leaves (1.5 times the maximum levels of sporulation that we detected) in streams with 1$2 \mathrm{mg} / \mathrm{L}$ nitrate- $\mathrm{N}$ but lower temperatures than occurred in the present study.

Most studies which have examined the effects of nutrients have concluded that $\mathrm{N}$ does not limit rates of leaf breakdown in streams. In Walker Branch, Oak Ridge, Tennessee, Newbold et al. (1983) found that enrichment with ammonium- $\mathrm{N}$ to a concentration of $100 \mu \mathrm{g} / \mathrm{L}$ did not stimulate rates of red oak leaf breakdown or microbial respiration in comparison to rates in a control reach in which total inorganic $\mathrm{N}$ concentrations averaged $31 \mu \mathrm{g} / \mathrm{L}$. In the same stream, enrichment with phosphate-P (from $3 \mu \mathrm{g} / \mathrm{L}$ in a control reach to 60 and $450 \mu \mathrm{g} / \mathrm{L}$ in two experimental reaches) stimulated rates of red oak leaf breakdown, microbial respiration associated with leaves, and immobilization of $\mathrm{N}$ and P by leaf detritus (Elwood et al. 1981). During these studies, the water in Walker Branch exhibited an average atomic ratio of inorganic N:P of 31-34:1 (Elwood et al. 1981, Newbold et al. 1983), suggesting that $\mathrm{P}$ was potentially limiting. In another study, Triska and Sedell (1976) concluded that nitrate amendments did not affect breakdown rates of four leaf species in experimental streams fed by a spring even though $\mathrm{N}: \mathrm{P}$ ratios in all the streams were low $(\approx 4-15)$. However, the rates of leaf breakdown in the experimental streams studied by Triska and Sedell (1976) were lower than found for the same species of leaves in natural streams in the area (Sedell et al. 1975). Since the experimental streams were fed by a spring and had no natural leaf inputs, they lacked invertebrate shredders (Triska and Sedell 1976). It is also possible that, because of lack of natural leaf litter in the experimental streams, there was a low inoculum of aquatic hyphomycete conidia in the water flowing over the leaves. Consequently, leaf breakdown, even in the high nitrate treatment, may have been limited by low fungal colonization.

Our results are in agreement with those of Meyer and Johnson (1983) who found greater rates of leaf breakdown and higher ATP concentrations associated with leaves decomposing in a stream that had contained 
TABLE 5. Fungal spora (concentration and species composition) in the water. Values represent mean with ranges in parentheses of total conidia concentrations and percentages of the conidia in the water.

\begin{tabular}{lcccccc}
\hline \hline & \multicolumn{5}{c}{ Hardwater streams } \\
\cline { 2 - 7 } \multicolumn{1}{c}{ Fungal species } & Schultz & B. Sandy 89 & B. Sandy 90 & Rocky Branch & Schultz & Cottingham \\
\hline Concentration (conidia/L) & 7450 & 2072 & 6460 & 6380 & 3780 & 4360 \\
& $(2310-14200)$ & $(800-8960)$ & $(2590-14360)$ & $(3110-14362)$ & $(1120-16070)$ & $(2280-8280)$ \\
Lunulospora curvula & $57(26-71)$ & $46(3-69)$ & $28(15-46)$ & $47(24-57)$ & $43(2-73)$ & $26(4-41)$ \\
Tetracladium marchalianum & $2(0-5)$ & $1(0-3)$ & $4(1-8)$ & $1(0-3)$ & 2 & $5(1-11)$ \\
Clavatospora tentacula & $1(0-2)$ & $5(1-8)$ & $34(3-50)$ & $5(1-10)$ & $2(0-6)$ & $0.4(0-1)$ \\
Triscelophorus konajensis & $5(2-8)$ & $5(0-10)$ & $8(5-12)$ & $3(1-6)$ & $1(0-4)$ & $5(3-7)$ \\
Alatospora acuminata & $1(0-3)$ & $4(1-12)$ & $4(1-16)$ & $13(5-29)$ & $8(2-16)$ & $37(16-56)$ \\
Campylospora chaetocladia & $5(1-13)$ & $6(0-13)$ & $9(7-13)$ & $9(5-18)$ & $3(0-10)$ & $3(1-5)$ \\
Clavariopsis aquatica & $0.6(0-3)$ & $1(0-5)$ & $1(0-4)$ & $0.7(0-3)$ & $\ldots$ & $\ldots$ \\
Tricladium chaetocladium & $1(0-5)$ & $2(0-7)$ & $2(1-6)$ & $0.2(0-1)$ & $\ldots$ & $\ldots$ \\
Crucella subtilis & $\ldots$ & $\ldots$ & $\ldots$ & $\ldots$ & $\ldots$ \\
Anguillospora filiformis & $1(0-5)$ & $10(0-51)$ & $0.3(0-2)$ & $0.1(0-1)$ & $1(0-9)$ & $\ldots$ \\
Unidentified sigmoid conidia & $18(4-50)$ & $22(7-34)$ & $9(3-16)$ & $21(12-32)$ & $34(8-72)$ & $19(12-30)$ \\
Other & $9(0-21)$ & $6(1-8)$ & $1(0-2)$ & $1(0-5)$ & $0.2(0-3)$ & $4(1-9)$ \\
\hline
\end{tabular}

a much higher concentration of nitrate $(129 \times)$ than another stream in a nearby watershed in the Appalachian Mountains of North Carolina. The differences in rates of leaf breakdown detected by Meyer and Johnson (1983) appear to be due to differences in nitrate concentration, although these two streams also differed in riparian vegetation and temperature, i.e., the high nitrate stream had been clear-cut in the past and had slightly higher temperature than the undisturbed stream. The phosphate concentration of both these streams was below the detection limit so N:P ratios could not be calculated. Other streams in this region appear to be P limited (Munn and Meyer 1990, Webster et al. 1991).

Although we placed leaves in streams in such a way to minimize losses due to invertebrate feeding in the present study, variation in nutrient concentrations could affect higher trophic levels in the detrital food chains of streams. Leaves colonized in streams containing low concentrations of nutrients would be expected to be lower in food quality due to the lower levels of fungal biomass than the same type of leaf colonized in streams containing high concentrations of nutrients. However, leaves are broken down more rapidly in streams with high concentrations of nutrients resulting in a narrower period of time during which the leaf detritus is at optimum palatability and food quality (sensu Boling et al. 1975). In such circumstances, foraging detritivores may have reduced access to optimally conditioned leaf detritus. In addition, sporulation of fungi appears to be stimulated more than growth by increased concentrations of nutrients. Since conidia typically contain high concentrations of energy reserves (e.g., lipids, polysaccharides), sporulation results in losses of highly nutritional material from detritus and such losses should cause a decline in the food quality of leaf detritus. It is difficult to predict how such activities would affect detritivore growth, and extensive data comparing activities of fungi with shredder growth and production in streams are not available. However, O'Hop et al. (1984) compared the energetics of the stonefly shredder, Peltoperla maria, in the two streams studied by Meyer and Johnson (1983) and found higher growth rates of the shredder in the stream containing higher nitrate concentrations. Overall densities of $P$. maria were lower in the high nitrate stream but annual production was similar in the two streams due to the more rapid growth and higher densities of larger nymphs in the high nitrate stream (O'Hop et al. 1984). Clearly comparisons of fungal growth rates in relationship to detritivore production in streams with different levels of nutrients are needed to address these types of questions more fully. However, from the evidence that is currently available, bottom-up effects appear to play major regulatory roles in detrital food chains of streams.

In contrast to periphyton communities, which derive their nutrients from the water, microorganisms colonizing leaves in streams have two potential sources of nutrients, the leaf and the water flowing over the leaf. Previous research has provided indirect evidence to suggest that fungi can obtain inorganic nutrients (N and P) from stream water. For example, Mulholland et al. (1985) found the greatest rates of phosphate uptake occurred during autumn after leaf fall when $\approx 50 \%$ of the whole stream phosphate uptake was by coarse particulate organic matter (mainly leaves). Although fungi were not examined specifically in that study, it is likely that fungi growing within leaves were responsible for the majority of such phosphate uptake. Decreases in both $\mathrm{N}$ and $\mathrm{P}$ concentrations of stream water during late autumn and winter have been attributed to uptake by microorganisms associated with leaf litter (Mulholland 1992). The exchange experiment we carried out provides further evidence that a major source of $\mathrm{N}$ and $\mathrm{P}$ for fungi growing in leaves is the water flowing across the leaf. The fungi associated with leaves responded rapidly to changing environmental conditions 
TABle 5. Continued.

\begin{tabular}{clll}
\hline \hline \multicolumn{4}{c}{ Softwater streams } \\
\hline Yellow & Mayfield & S. Sandy 89 & S. Sandy 90 \\
\hline 3530 & 3650 & 4690 & 3890 \\
$(800-5880)$ & $(880-6130)$ & $(990-7550)$ & $(2470-7370)$ \\
$8(0-22)$ & $8(0-20)$ & $11(0-29)$ & $10(1-36)$ \\
$\ldots$ & $\ldots$ & $\ldots$ & $\ldots$ \\
$\ldots$ & $\ldots$ & $\ldots$ & $\ldots$ \\
$0.3(0-1)$ & $\ldots$ & $\ldots$ & $\ldots$ \\
$0.1(0-1)$ & $\ldots$ & $\ldots$ & $\ldots .7(0-6)$ \\
$\ldots$ & $\ldots$ & $\ldots$ & $\ldots$ \\
$\ldots$ & $\ldots$ & $\ldots$ & $\ldots$ \\
$\ldots$ & $\ldots$ & $63(43-76)$ & $66(35-91)$ \\
$3(0-6)$ & $\ldots$ & $26(11-61)$ & $20(4-46)$ \\
$28(16-57)$ & $59(36-84)$ & $1(0-4)$ & $1(0-4)$ \\
$55(35-73)$ & $32(13-64)$ & & \\
$0.7(0-5)$ & $1(0-3)$ & & \\
\hline
\end{tabular}

surrounding the leaves. Both sporulation and biomass were at high levels in Big Sandy after 9 d, but declined rapidly when leaves were transferred to South Sandy which contained low concentrations of nutrients. The fungi on such leaves (i.e., South Sandy exchange), apparently did not contain reserve nutrients that they could recycle rapidly enough to maintain the same level of activity that they exhibited in the stream with higher nutrient concentrations. It is also apparent that they could not obtain these nutrients from the leaf tissue rapidly enough to maintain the same level of activity. Conversely, when leaves were transferred to a stream with higher concentration of nutrients, there was a rapid colonization by fungi indigenous to that stream (i.e., Big Sandy exchange). Within a short period of time, these leaves became similar to leaves which had been colonized in that stream for the entire period with respect to species composition, total biomass, and breakdown rate.

The fungal community colonizing leaves in Big Sandy persisted after transfer to South Sandy (South Sandy X), but the fungi of the community in South Sandy did not persist and were replaced by fungi native to Big Sandy (Big Sandy X) even though conditions in Big Sandy in general appeared to be more favorable for fungal growth. The dominant fungus on leaves in South Sandy, A. filiformis, should have colonized leaves after the initial $9 \mathrm{~d}$ of submergence in this stream. This fungus occurs in hardwater streams (Table 6 ), and we have also observed it growing (although never dominant) on leaves in Big Sandy indicating that it is not totally inhibited by the conditions in this stream (high $\mathrm{pH}$ ). Other factors, e.g., competition with species adapted to hardwater streams, may have prevented $A$. filiformis from remaining as the dominant fungus on leaves once they were transferred to Big Sandy. Previous studies that have transplanted leaves colonized by particular fungal species or assemblages from one habitat to another have yielded variable results depending on the species and the length of time of initial colonization (Suberkropp 1984, Rosset and Bärlocher 1985).

Alkalinity and $\mathrm{pH}$ had major effects on the species composition of the fungal community colonizing leaves. It is difficult to determine how these factors affected levels of fungal activity and rates of leaf breakdown, due to differences in nutrient concentrations among the softwater and hardwater streams we examined. In the present study, streams with similar nitrate concentration but different phosphate concentrations (compare Cottingham and Little Schultz with Yellow, Tables 1 and 2) exhibited similar rates of leaf breakdown. However, when concentrations of nutrients are similar, fungal activity and rates of breakdown can be greater in hardwater streams than in softwater streams (Rosset et al. 1982). This may be due, at least in part, to the differences in activities of different types of enzymes produced by the microbial community colonizing leaves in streams of different $\mathrm{pH}$ and alkalinity. Communities on leaves in hardwater streams produce greater activities of pectin lyase which leads to greater leaf softening and maceration than occurs in softwater streams (Jenkins and Suberkropp 1995). Alkalinity and $\mathrm{pH}$ have also been demonstrated to affect the species richness of aquatic hyphomycetes, with softwater streams typically containing higher numbers of species than hardwater streams (Bärlocher and Rosset 1981, Bärlocher 1982, Wood-Eggenschwiler and Bärlocher 1983, Chauvet 1991). In this study, all streams exhibited low species richness and the softwater streams were extremely depauperate, perhaps due to other factors (e.g., low leaf retentiveness, low nutrient concentrations, mycoparasitism).

Rates of leaf breakdown are controlled by activities of decomposer microorganisms, primarily fungi (Gessner and Chauvet 1994). Factors affecting the activities of the fungi also affect rates of leaf breakdown. These include both internal, (e.g., substrate quality), and ex-

TABLE 6. Fungal community composition of yellow poplar leaves that had been colonized for $9 \mathrm{~d}$ in Big Sandy and placed in South Sandy (B. Sandy X) or colonized for $9 \mathrm{~d}$ in South Sandy and placed in Big Sandy (S. Sandy X). Numbers represent the percentage of the conidia produced after leaves had been in the second stream for $12 \mathrm{~d}$. Species present at other times indicated with + ; species not detected indicated with - .

\begin{tabular}{lcc}
\hline \hline \multirow{2}{*}{\multicolumn{1}{c}{ Fungal species }} & \multicolumn{2}{c}{ Treatment } \\
\cline { 2 - 3 } & B. Sandy X & S. Sandy X \\
\hline Lunulospora curvula & 2 & 37 \\
Tetracladium marchalianum & 16 & 8 \\
Clavatospora tentacula & 64 & 41 \\
Triscelophorus konajensis & 15 & + \\
Alatospora acuminata & - & + \\
Campylospora chaetocladia & + & + \\
Clavariopsis aquatica & 2 & 3 \\
Flagellospora penicillioides & 1 & 3 \\
Tricladium chaetocladium & - & 7 \\
Anguillospora filiformis & + & 1 \\
\hline
\end{tabular}


ternal, (e.g., temperature) factors (Mellilo et al. 1984). In a comparison of seven leaf species in a stream, Gessner and Chauvet (1994) found that rates of leaf breakdown and fungal activity were correlated with lignin content and, to a lesser extent, tannin concentration of the leaves. Their results indicate that the quality and availability of organic carbon to fungi can control the rates of leaf breakdown. In other studies of leaf breakdown in both stream and terrestrial environments, a variety of factors related to substrate quality (e.g., initial nitrogen content, $\mathrm{C}: \mathrm{N}$ ratios, initial lignin content, initial ratios of lignin to nitrogen) have been found to regulate rates of litter breakdown (Fogel and Cromack 1977, Meentemeyer 1978, Mellilo et al. 1982, Taylor et al. 1989). Likewise external factors such as temperature affect the metabolism of fungal decomposers and have been demonstrated to affect the rates of leaf breakdown in streams (Suberkropp et al. 1975, Webster and Benfield 1986, McArthur et al. 1988). The results of the present study indicate that the chemistry of the water, particularly its nutrient content, can also regulate leaf breakdown by affecting the activity of decomposer fungi. It is likely that nutrients such as nitrogen and phosphorus can function as either internal or external regulators depending on their concentrations in the litter and the environment (Mellilo et al. 1982). In terrestrial environments and streams with low nutrient concentrations, where external sources of nutrients are unavailable, nutrient concentration within the leaf may assume a more important role in the regulation of breakdown rates. However, higher concentrations of nutrients in some environments may override the effects that internal nutrient concentration may have. For example, the stream studied by Gessner and Chauvet (1994) had a moderate concentration of nitrate and, in this stream, nitrogen content of leaves was not a good predictor of either fungal activity or breakdown rate of leaves. This suggests that the majority of the $\mathrm{N}$ requirement of fungi came from the water flowing over the leaf surface rather than from the leaf tissue. On the basis of our results, it appears that, in streams, the effects of external concentrations of nutrients on fungal reproduction (sporulation) are greater than their effects on rates of fungal biomass accumulation or leaf breakdown. Overall, both internal and external factors and, particularly, their potential interaction appear to be important in the regulation of fungal mediated breakdown of leaf litter.

\section{ACKNOWLEDGMENTS}

We thank A. A. Gibson for excellent technical assistance during the study, S. Evces for assistance with nutrient analyses of water samples, and Drs. M. O. Gessner, N. Grimm, and two anonymous reviewers for valuable suggestions concerning earlier versions of the manuscript. This research was supported by Grant BSR-8705486 from the National Science Foundation and an exchange grant from the Centre National de la Recherche Scientifique and the National Science Foundation.

\section{Literature Cited}

Bärlocher, F. 1982. Conidium production from leaves and needles in four streams. Canadian Journal of Botany 60: 1487-1494.

. 1985. The role of fungi in the nutrition of stream invertebrates. Botanical Journal of the Linnean Society 91: 83-94.

Bärlocher, F., and J. Rosset. 1981. Aquatic hyphomycete spora of two Black Forest and two Swiss Jura streams. Transactions of the British Mycological Society 76:479483.

Boling, R. H., E. D. Goodman, J. A. Van Sickle, J. O. Zimmer, K. W. Cummins, R. C. Petersen, and S. R. Reice. 1975. Toward a model of detritus processing in a woodland stream. Ecology 56:141-151.

Bott, T. L. 1983. Primary productivity in streams. Pages 2954 in J. R. Barnes and G. W. Minshall, editors. Stream ecology: application and testing of general ecological theory. Plenum, New York, New York, USA.

Chamier, A.-C. 1992. Water chemistry. Pages 152-172 in F. Bärlocher, editor. The ecology of aquatic hyphomycetes. Springer-Verlag, Berlin, Germany.

Chauvet, E. 1987. Changes in the chemical composition of alder, poplar and willow leaves during decomposition in a river. Hydrobiologia 148:35-44.

-. 1991. Aquatic hyphomycete distribution in southwestern France. Journal of Biogeography 18:699-706.

Elwood, J. W., J. D. Newbold, A. F. Trimble, and R. W. Stark. 1981. The limiting role of phosphorus in a woodland stream ecosystem: Effects of P enrichment on leaf decomposition and primary producers. Ecology 62:146-158.

Fairchild, J. F., T. P. Boyle, E. Robinson-Wilson, and J. R. Jones. 1984. Effects of inorganic nutrients on microbial leaf decomposition and mitigation of chemical perturbation. Journal of Freshwater Ecology 2:405-416.

Findlay, S. E. G., and T. L. Arsuffi. 1989. Microbial growth and detritus transformations during decomposition of leaf litter in a stream. Freshwater Biology 21:261-269.

Fisher, S. G., and G. E. Likens. 1973. Energy flow in Bear Brook, New Hampshire: an integrative approach to stream ecosystem metabolism. Ecological Monographs 43:421439.

Fogel, R., and K. Cromack, Jr. 1977. Effect of habitat and substrate quality on Douglas-fir litter decomposition in western Oregon. Canadian Journal of Botany 55:16321640.

Gessner, M. O., and E. Chauvet. 1994. Importance of stream microfungi in controlling breakdown rates of leaf litter. Ecology 75:1807-1817.

Grimm, N. B., and S. G. Fisher. 1986. Nitrogen limitation in a Sonoran desert stream. Journal of the North American Benthological Society 5:2-15.

Hart, D. D., and C. T. Robinson. 1990. Resource limitation in a stream community: Phosphorus enrichment effects on periphyton and grazers. Ecology 71:1494-1502.

Howarth, R. W., and S. G. Fisher. 1976. Carbon, nitrogen, and phosphorus dynamics during leaf decay in nutrientenriched stream microecosystems. Freshwater Biology 6: 221-228.

Hynes, H. B. N., and N. K. Kaushik. 1969. The relationship between dissolved nutrient salts and protein production in submerged autumnal leaves. Internationale Vereinigung für theoretische und angewandte Limnologie Verhandlungen 17:95-103.

Iqbal, S. H., and J. Webster. 1973. Aquatic hyphomycete spora of the River Exe and its tributaries. Transactions of the British Mycological Society 61:233-241.

Jenkins, C. C., and K. Suberkropp. 1995. The influence of water chemistry on the enzymatic degradation of leaves in streams. Freshwater Biology 33, in press. 
McArthur, J. V., J. R. Barnes, and B. J. Hansen. 1988. Seasonal dynamics of leaf litter breakdown in a Utah alpine stream. Journal of the North American Benthological Society 7:44-50.

Meentemeyer, V. 1978. Macroclimate and lignin control of litter decomposition rates. Ecology 59:465-472.

Mellilo, J. M., J. D. Aber, and J. F. Muratore. 1982. Nitrogen and lignin control of hardwood leaf litter decomposition dynamics. Ecology 63:621-626.

Mellilo, J. M., R. J. Naiman, J. D. Aber, and A. E. Linkins. 1984. Factors controlling mass loss and nitrogen dynamics of plant litter decaying in northern streams. Bulletin of Marine Science 35:341-356.

Meyer, J. L., and C. Johnson. 1983. The influence of elevated nitrate concentration on rate of leaf decomposition in a stream. Freshwater Biology 13:177-183.

Meyer, J. L., W. H. McDowell, T. L. Bott, J. W. Elwood, C. Ishizaki, J. M. Melack, B. L. Peckarsky, B. J. Peterson, and P. A. Rublee. 1988. Elemental dynamics in streams. Journal of the North American Benthological Society 7: 410-432.

Minshall, G. W., R. C. Petersen, K. W. Cummins, T. L. Bott, J. R. Sedell, C. E. Cushing, and R. L. Vannote. 1983. Interbiome comparison of stream ecosystem dynamics. Ecological Monographs 53:1-25.

Mulholland, P. J. 1992. Regulation of nutrient concentrations in a temperate forest stream: roles of upland, riparian, and instream processes. Limnology and Oceanography 37: $1512-1526$

Mulholland, P. J., J. D. Newbold, J. W. Elwood, L. A. Ferren, and J. R. Webster. 1985. Phosphorus spiralling in a woodland stream: seasonal variations. Ecology 66:1012-1023.

Munn, N. L., and J. L. Meyer. 1990. Habitat-specific solute retention in two small streams: an intersite comparison. Ecology 71:2069-2082.

Newbold, J. D., J. W. Elwood, M. S. Schulze, R. W. Stark, and J. C. Barmeier. 1983. Continuous ammonium enrichment of a woodland stream: uptake kinetics, leaf decomposition, and nitrification. Freshwater Biology 13:193-204.

O'Hop, J., J. B. Wallace, and J. D. Haefner. 1984. Production of a stream shredder, Peltoperla maria (Plecoptera: Peltoperlildae) in disturbed and undisturbed hardwood catchments. Freshwater Biology 14:13-21.

Petersen, R. C., and K. W. Cummins. 1974. Leaf processing in a woodland stream. Freshwater Biology 4:343-368.

Peterson, B. J., L. Deegan, J. Helfrich, J. E. Hobbie, M. Hullar, B. Moller, T. E. Ford, A. Hershey, A. Hiltner, G. Kipphut, M. A. Lock, D. M. Fiebig, V. McKinley, M. C. Miller, J. R. Vestal, R. Ventullo, and G. Volk. 1993. Biological responses of a tundra river to fertilization. Ecology 74:653-672.

Pringle, C. M. 1987. Effects of water and substratum nutrient supplies on lotic periphyton growth: an integrated bioassay. Canadian Journal of Fisheries and Aquatic Sciences 44: 619-629.

Rosemond, A. D., P. J. Mulholland, and J. W. Elwood. 1993. Top-down and bottom-up control of stream periphyton: effects of nutrients and herbivores. Ecology 74:1264-1280.

Rosset, J., and F. Bärlocher. 1985. Transplant experiments with aquatic hyphomycetes. Internationale Vereinigung für theoretische und angewandte Limnologie Verhandlungen 22:2786-2790.

Rosset, J., F. Bärlocher, and J. J. Oertli. 1982. Decomposition of conifer needles and deciduous leaves in two Black Forest and two Swiss Jura streams. Internationale Revue der gesamten Hydrobiologie 67:695-711.

Sedell, J. R., F. J. Triska, and N. S. Triska. 1975. The processing of conifer and hardwood leaves in two coniferous forest streams. Internationale Vereinigung für theoretische und angewandte Limnologie Verhandlungen 19:16171627.

Suberkropp, K. 1984. Effect of temperature on seasonal occurrence of aquatic hyphomycetes. Transactions of the British Mycological Society 82:53-62.

. 1991. Relationships between growth and sporulation of aquatic hyphomycetes on decomposing leaf litter. Mycological Research 95:843-850.

. 1992. Interactions with invertebrates. Pages 118134 in F. Bärlocher, editor. The ecology of aquatic hyphomycetes. Springer-Verlag, Berlin, Germany.

Suberkropp, K., T. L. Arsuffi, and J. P. Anderson. 1983. Comparison of the degradative ability, enzymatic activity and palatability of aquatic hyphomycetes grown on leaf litter. Journal of Applied and Environmental Microbiology 46: 237-244.

Suberkropp, K., and M. J. Klug. 1976. Fungi and bacteria associated with leaves during processing in a woodland stream. Ecology 57:707-719.

Suberkropp, K., and M. J. Klug. 1980. The maceration of deciduous leaf litter by aquatic hyphomycetes. Canadian Journal of Botany 58:1025-1031.

Suberkropp, K., M. J. Klug, and K. W. Cummins. 1975. Community processing of leaf litter in woodland streams. Internationale Vereinigung für theoretische und angewandte Limnologie Verhandlungen 19:1653-1658.

Taylor, B. R., D. Parkinson, and W. F. J. Parsons. 1989. Nitrogen and lignin content as predictors of litter decay rates: A microcosm test. Ecology 70:97-104.

Triska, F. J., and J. R. Sedell. 1976. Decomposition of four species of leaf litter in response to nitrate manipulation. Ecology 57:783-792.

Ward, A. K., G. M. Ward, and S. C. Harris. 1992. Water quality and biological communities of the Mobile River drainage, Eastern Gulf of Mexico region. Pages 279-304 in C. D. Becker and D. A. Neitzel, editors. Water quality in North American river systems. Battelle, Columbus, Ohio, USA.

Webster, J. R., and E. F. Benfield. 1986. Vascular plant breakdown in freshwater ecosystems. Annual Review of Ecology and Systematics 17:567-594.

Webster, J. R., D. J. D’Angelo, and G. T. Peters. 1991. Nitrate and phosphate uptake in streams at Coweeta Hydrologic Laboratory. Internationale Vereinigung für theoretische und angewandte Limnologie Verhandlungen 24:16811686.

Wilkinson, L. 1990. Systat: the system for statistics. Systat, Evanston, Illinois, USA.

Wood-Eggenschwiler, S., and F. Bärlocher. 1983. Aquatic hyphomycetes in sixteen streams in France, Germany and Switzerland. Transactions of the British Mycological Society 81:371-379.

Zar, J. H. 1984. Biostatistical analysis. Second edition. Prentice Hall, Englewood Cliffs, New Jersey, USA. 